\title{
Statyba
}

\section{THE INFLUENCE OF COARSE AGGREGATE CONCENTRATION ON THE STRENGTH OF CONCRETE AND ON THE POROSITY OF CONCRETE MORTAR}

\section{G. Skripkiūnas \& V. Vaitkevičius MSc}

To cite this article: G. Skripkiūnas \& V. Vaitkevičius MSc (2001) THE INFLUENCE OF COARSE AGGREGATE CONCENTRATION ON THE STRENGTH OF CONCRETE AND ON THE POROSITY OF CONCRETE MORTAR, Statyba, 7:6, 446-452, DOI: 10.1080/13921525.2001.10531771

To link to this article: https://doi.org/10.1080/13921525.2001.10531771

曲 Published online: 30 Jul 2012.

Submit your article to this journal ¿

Џ Article views: 72 


\section{STAMBIOJO UŽPILDO KONCENTRACIJOS ITAKA BETONO STIPRUMUI IR SKIEDININĖS DALIES PORINGUMUI}

\section{G. Skripkiūnas, V. Vaitkevičius}

Kauno technologijos universitetas

\section{Ivadas}

Betono stiprumą lemia cementinio akmens stiprumas, tačiau užpildai taip pat jam daro žymią itaką. Laikoma, kad betono stiprumas priklauso nuo stambiojo užpildo stiprumo tik tada, kai stambiojo užpildo stiprumas mažesnis už cementinio akmens stiprumą.

Daugeliu tyrimu nustatyta, kad stambiojo užpildo kiekis ir jo stambumas betono stiprumui turi itakos tiek, kiek pakeičia betono mišinio vandens poreiki, tačiau mažai nagrinėtas stambiojo užpildo poveikis betono poringumui ir itempimu koncentracijoms betone, nuo kuriu taip pat priklauso betono stiprumas. Iki šiol atlikti tik teoriniai betone atsirandančių itempimų koncentraciju apie stambuji užpildą skaičiavimai, tačiau eksperimentais tai neịrodyta dèl netinkamų tyrimo metodikų atliekant eksperimentus neatsižvelgiama i betono skiedininès dalies struktūros ir savybiụ pasikeitimus, kintant stambiojo užpildo koncentracijai.

Šị tyrimų tikslas buvo nustatyti, kaip keičiasi betono skiedininès dalies poringumas ir itempimu koncentracijos joje, kintant stambiojo užpildo kiekiui betone, ir ištirti stambiojo užpildo ịtaką betono stiprumui, esant tam pačiam oro kiekiui betone.

\section{Itempimų koncentracijos apkrautame betone}

Apkrovus betoną, stambusis užpildas jame sukelia itempimų koncentracijas. Ypač pavojingi betone tempimo itempimai, nes betono arba skiedinio stiprumas tempiant sudaro tik nuo $1 / 6$ iki $1 / 20$ stiprumo gniuždant. A. E. Desovo nuomone, didžiausi tempimo ittempimai gniuždomame betone susidaro skiedinyje virš ir po stambiuoju užpildu (taškuose B ir D) (1 pav.). Absoliučiu dydžiu jie prilygsta gniuždymo ịtempimams, kuriais veikiamas betonas. Didžiausi gniuždymo itempimai susidaro šalia stambiojo užpildo (taškuose $A$ ir $C$ ) (1 pav.).
Dèl stambiojo užpildo sukeliamy ittempimu koncentracijų gniuždymo jtempimai betone padideja iki trijų kartụ, o esant mažiems intarpams šalia stambiojo užpildo - iki devynių kartu [1, 2]. Šie rezultatai gauti sprendžiant plokščią tamprumo teorijos uždavini, analizuojant gniuždomą plokštelę su kiauryme, ir daugiau taikytini betonams su silpnu poringu užpildu.

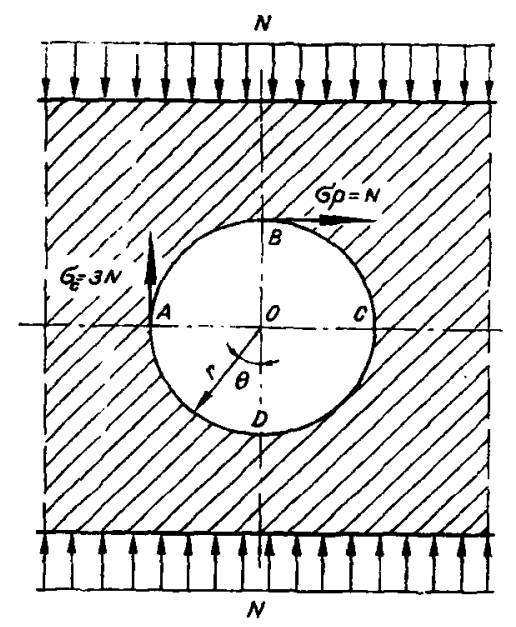

1 pav. Itempimu pasiskirstymas betone apie poringą stambuji užpilda

Fig 1. Distribution of stresses in the concrete near porous coarse aggregate

Minėtus samprotavimus patvirtina ir I. N. Achverdovo atlikti eksperimentai, naudojant plokščius modelius su optiškai jautrios medžiagos matrica ir užpildais iš cementinio akmens. Poliarizaciniu-optiniu metodu buvo nustatyti itempimai ir apskaičiuotas tempimo itempimu koncentracijos koeficientas:

$$
K_{\tau}=\tau_{\max } / \tau_{v i d}
$$

$\tau_{\text {max }}$ - maksimalūs tempimo ittempimai, susidarantys gniuždomame betone; $\tau_{v i d}-$ vidutiniai tempimo itempi- 
mai gniuždomame betone. Šie tyrimai parodè, kad itempimų koncentracijos koeficientas $K_{\tau}$ priklauso nuo stambiojo užpildo ir skiedinio tamprumo modulių santykio $E_{s t} / E_{s k}$ bei stambiojo užpildo koncentracijos betone. Didèjant $E_{s t} / E_{s k}$, proporcingai didejja ir koeficientas $K_{\tau}$, o esant pastoviam $E_{s t} / E_{s k}$, koeficientas $K_{\tau}$ dideja, didejant stambiojo užpildo koncentracijai betone. Kai stambiojo užpildo betone yra mažiau negu $20 \%$, itempimy koncentracijos betone minimalios $\left(K_{\tau} \approx 1\right)$ nepriklausomai nuo $E_{s t} / E_{s k}$, o, esant maksimaliai stambiojo užpildo koncentracijai betone ir $E_{s t} / E_{s k}=3$, koeficiento $K_{\tau}$ reikšmé padidèja iki 2,4-2,7 [3].

$\mathrm{Kad} E_{s t} / E_{s k}$ turi itakos itempiu koncentracijai betone, patvirtina A. S. Dmitrijevo bandymai, atlikti su betonais, kuriuose kaip stambusis užpildas buvo panaudoti plieno gabalai. Tokių betonų prizminis stiprumas buvo daug mažesnis negu betonı su kalkakmenio užpildu [4].

O. J. Bergas, su bendradarbiais, nagrinèdamas itempimų pasiskirstymą trimatèje tampriojoje erdvejje su sferiniu intarpu iš tampresnès medžiagos, esant vienašiam gniuždymui, padarè išvadą, kad tempimo itempimai atsiranda skiedinyje šoninèje stambiojo užpildo zonoje, o gniuždymo ittempimai - skiedinyje, esančiame stambiojo užpildo viršutinèje ir apatinéje dalyse (2 pav.) [5, 6].

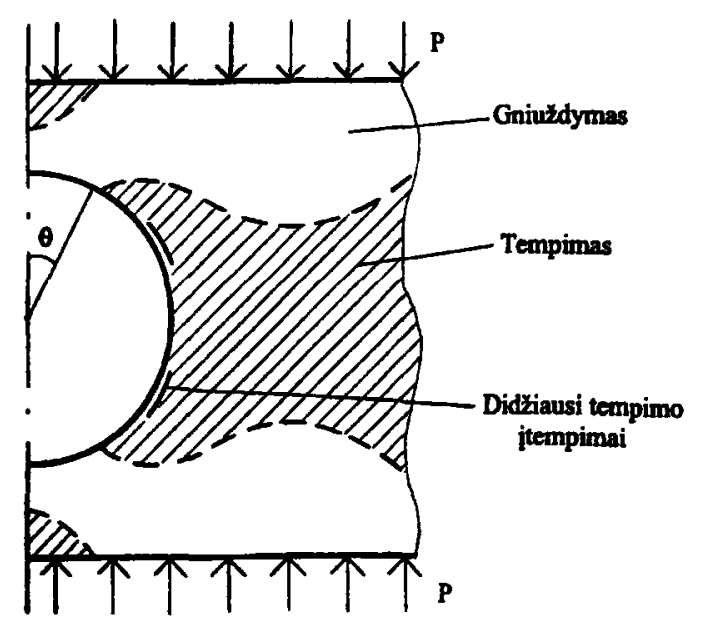

2 pav. Itempimu pasiskirstymas betone apie tankų stambuji užpildą

Fig 2. Distribution of stresses in the concrete near dense coarse aggregate
Didžiausi tempimo itempimai atsiranda skiedinio ir stambiojo užpildo kontakto zonoje, kai kampas $\theta \approx 60^{\circ}$ (kiekviename stambiojo užpildo simetriniame ketvirtyje). Tolstant nuo stambiojo užpildo paviršiaus, ir tempimo, ir gniuždymo ittempimų koncentracijos koeficientai staigiai mažèja. Panašius rezultatus gavo S. P. Shah ir G. Winteris, tirdami plyšių atsiradimą apie sferinius užpildus idealizuotame betono modelyje [7], N. I. Netesa, taikydamas baigtiniu elementı metodą [8], bei Novosibirsko inžinerinio statybos instituto mokslininkai, modeliuodami betono struktūrą baigtinių elementų metodu [9].

Maksimali tempimo itempimų koncentraciju reikšmè priklauso nuo stambiojo užpildo ir skiedinio tamprumo moduliu santykio ir, kai šis santykis 2, ji lygi $0,15 P$, kur $P$ - gniuždymo itempimai, kuriais apkrautas betonas. Kai užpildas kubinès formos, gaunami didesni itempimu koncentracijos koeficientai ir pačiu netinkamiausiu šiu užpildy išsidèstymo atveju gali $25 \%$ viršyti įtempimų koncentracijos koeficientų reikšmes su sferiniais užpildais. Užpildo tūrinei koncentracijai betone didejant nuo 0,5 iki 0,7 , tempimo itempimų koncentracijos koeficientai padidèja nuo $10 \%$ iki $15 \%$, o, kai užpildai kubinès formos, - iki 30\% [8].

Didžiausių tempimo itempimų koncentraciju vietoje - stambiojo užpildo ir skiedinio kontakto zonoje (2 pav.), kai tempimo įtempimai viršija stambiojo užpildo ir skiedinio sukibimo stipruma, atsiranda mikroplyšiu, kurių kryptis beveik sutampa su jègos veikimo kryptimi. Žemų klasių betonuose pradžioje gali atsirasti išilginių mikroplyšių skiedinyje tarp stambiojo užpildo daleliu (virš ir po jomis) jègos veikimo kryptimi, nes šioje vietoje taip pat atsiranda tempimo i̇tempimu koncentracijos. Šie plyšiai atsiranda tada, kai atsiradę tempimo ịtempimai viršija skiedinio stiprumą tempiant [6]. Tai rodo, kad aukštų klasių betonams ypač svarbus užpildo sukibimas su cementiniu akmeniu, tuo tarpu žemų klasių betonams svarbesnis skiedinio stiprumas tempiant.

Prancūzų mokslininkai, tyrinejję betono stiprumo priklausomybę nuo skirtingu stambiuju užpildu, eksperimentais irode, kad cementinio akmens ir skiedinio stiprumas visada didesnis už betono stiprumą [10].

\section{Tyrimų metodika}

Norint nustatyti stambiojo užpildo kiekio itaką betono fizikinèms ir mechaninèms savybẻms, betono mi- 
šiniai buvo ruošiami su trimis $\mathrm{V} / \mathrm{C}$ santykiais $(\mathrm{V} / \mathrm{C}=0,3$; $\mathrm{V} / \mathrm{C}=0,4 ; \mathrm{V} / \mathrm{C}=0,6)$, kuriu skiedininè dalis buvo vienoda, keitèsi tik stambiojo užpildo koncentracija $\varphi_{s t}-$ nuo 0 iki 0,5 .

Bandymams naudotas portlandcementis CEM I 52,5, pagamintas $A B$ „Akmenés cementas“, kurio savitasis paviršius $-370 \mathrm{~m}^{2} / \mathrm{kg}$, vandens kiekis normalaus tirštumo tešlai $-27,25 \%$. Kaip tankus stambusis užpildas buvo naudojama dvieju frakciju $4 / 8 \mathrm{~mm}$ ir $8 / 16$ mm granitinè skalda, pagaminta $\mathrm{AB}$ „Granitas", kurios vidutinis daleliụ tankis $-2650 \mathrm{~kg} / \mathrm{m}^{3}$, skalumas $-7,3 \%$, markè pagal stiprumą - 1400 . Kaip poringas užpildas buvo naudojamas dvieju frakciju $4 / 8 \mathrm{~mm}$ ir $8 / 16 \mathrm{~mm}$ keramzito žvirgždas, pagamintas $A B$ „Palemono keramika“, kurio vidutinis daleliu tankis $-741 \mathrm{~kg} / \mathrm{m}^{3}$, poringumas $-66,3 \%$, vandens igèris $-16,3 \%$ ir cilindrinis stiprumas - 0,93 MPa. Tyrimams buvo naudojamas Zatyšiu karjero smèlis, kurio stambumo modulis - 2,5.

Betono mišiniams paruošti buvo naudojami sausi užpildai. Cementas ir užpildai buvo dozuojami pagal mase, o vanduo ir plastifikuojantis priedas - pagal tūrị. Betono mišiniai $3 \mathrm{~min}$. buvo maišomi laboratorinèje 501 gravitacinèje maišyklèje.

Betono savybèms nustatyti buvo formuojami bandiniai $-10 \times 10 \times 10 \mathrm{~cm}$ kubai. Esant normaliam betono mišinio slankumui $(\mathrm{V} / \mathrm{C}=0,3 ; \mathrm{V} / \mathrm{C}=0,4)$, bandiniai buvo formuojami iš karto. Esant $\mathrm{V} / \mathrm{C}=\mathbf{0}, 6$, betono mišiniai buvo labai plastiški, todèl periodiškai permaišant buvo laukiama, kol jie pradès rištis, ir tik tada buvo formuojami bandiniai. Taip daryta tam, kad formuojant bandinius betono mišiniai neišsisluoksniuotu ir neatsiskirtu vanduo. Betono su skirtinga stambiojo užpildo (keramzito) koncentracija struktūra parodyta 3 pav. Stambiojo užpildo dalelès pasiskirsto tolygiau, kuo didesnè stambiojo užpildo koncentracija.

Bandiniai išbandyti po 28 paru kietejimo režiminëje kameroje $\left(20 \pm 2 \mathrm{C}^{\circ}\right.$ temperatūra, $95 \pm 5 \%$ santykinè drégmè). Betono atviras poringumas (kapiliarinis poringumas) nustatytas pagal vandens igèrí, o uždaras poringumas (oro kiekis betone) - pagal betono tanki ir savitaji tanki. Skiedinio poringumas apskaičiuotas pagal betono poringumą, stambiojo užpildo poringumą ir skiedinio kieki betone. Skaičiuojant skiedinio poringumą laikyta, kad tankaus stambiojo užpildo (granitinès skaldos) poringumas lygus nuliui.

\section{Tyrimų rezultatai}

Betono fizikinès ir mechaninès savybès buvo tiriamos keičiant stambiojo užpildo koncentracija, tačiau esant pastoviam V/C santykiui ir cementinès tešlos kiekiui skiedinyje. Tyrimu rezultatai pateikti 1 ir 2 lentelèse.

Kaip matyti iš 1 ir 2 lentelių bei 4 ir 5 pav., didejant tankaus stambiojo užpildo koncentracijai betone, jo stipris gniuždant didèja, o, didèjant poringo stambiojo užpildo koncentracijai betone, jo stipris gniuždant mažèja. Tačiau kintant stambiojo užpildo koncentracijai, žymiai keičiasi ir oro kiekis betono mišinyje bei betone ( 1 ir 2 lentelès), kuris taip pat turi didelès itakos betono stiprumui. Žinoma, kad $1 \%$ sulaikyto oro betone sumažina betono stiprumą apie 5\% [11].

Ivertinę oro kiekio itaką betono stiprumui, gauname 4 ir 5 pav. pavaizduotas kreives, kurios rodo, kad stambiojo užpildo koncentracijos didejimas turi neigiamos itakos betono stiprumui, kai oro kiekis betone yra pastovus.

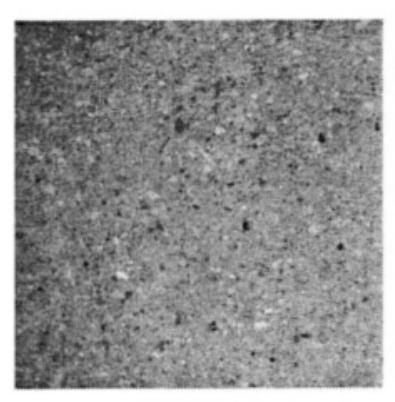

a)

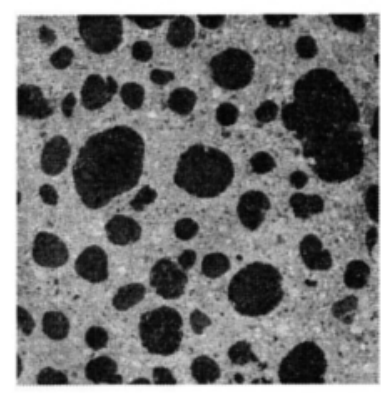

c)

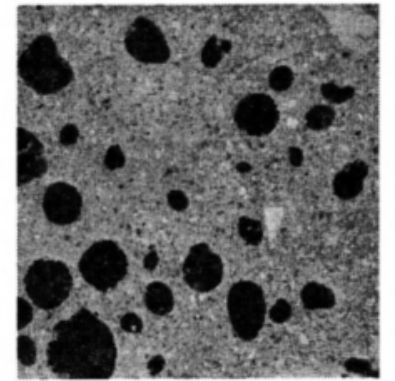

b)

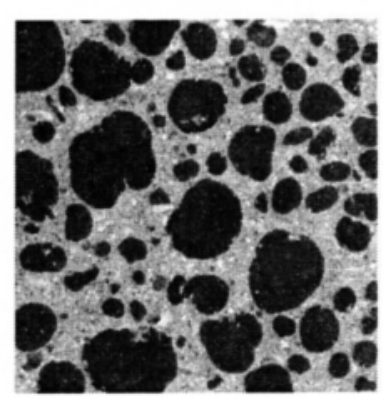

d)
3 pav. Keramzitbetonio bandinių skelto paviršiaus vaizdas, esant skirtingai stambiojo užpildo koncentracijai $\varphi_{s t}$ : $\mathrm{a}-0, \mathrm{~b}-0,15, \mathrm{c}-0,3, \mathrm{~d}-0,5$

Fig 3. The wiew of the broken surface of expanded clay aggregate concrete with different volumetric concentration of coarse aggregate $\varphi_{s t}: \mathrm{a}-0, \mathrm{~b}-0.15, \mathrm{c}-$ $0.3, \mathrm{~d}-0.5$ 
1 lentelè. Betonų su tankiu stambiuoju užpildu (granitine skalda) fizikinès ir mechaninès savybès

Table 1. Physical and mechanical properties of the concretes with dense coarse aggregate (crushed granite)

\begin{tabular}{|c|c|c|c|c|c|c|}
\hline \multirow{2}{*}{$\varphi_{s t}$} & \multirow{2}{*}{$\begin{array}{c}\text { Tankis, } \\
\mathrm{kg} / \mathrm{m}^{3}\end{array}$} & $\begin{array}{c}\text { Stipris } \\
\text { gniuždant, } \\
\text { MPa }\end{array}$ & \multicolumn{6}{|c|}{ Oro kiekis, \% } & \multicolumn{2}{c|}{$\begin{array}{c}\text { Kapiliarinis } \\
\text { poringumas, \% }\end{array}$} \\
\cline { 4 - 7 } & betone & $\begin{array}{c}\text { skiedi- } \\
\text { nyje }\end{array}$ & betone & $\begin{array}{c}\text { skiedi- } \\
\text { nyje }\end{array}$ \\
\hline 0 & 2233 & 52,2 & 4,9 & 4,9 & 18,5 & 18,5 \\
\hline 0,15 & 2295 & 55,1 & 3,5 & 4,1 & 16,4 & 19,3 \\
\hline 0,3 & 2435 & 57,4 & 2,1 & 3,0 & 13,2 & 18,9 \\
\hline 0,5 & 2510 & 61,0 & 0,6 & 1,2 & 9,9 & 19,8 \\
\hline \multicolumn{7}{|c|}{ V/C $=0,4$} \\
\hline 0 & 2217 & 49,5 & 3,9 & 3,9 & 19,3 & 19,3 \\
\hline 0,15 & 2305 & 49,5 & 2,7 & 3,2 & 17,5 & 20,6 \\
\hline 0,3 & 2376 & 50,8 & 2,0 & 2,9 & 14,3 & 20,4 \\
\hline 0,5 & 2460 & 53,8 & 0,6 & 1,2 & 12,1 & 24,2 \\
\hline \multicolumn{7}{|c|}{ V/C $=0,6$} \\
\hline 0 & 2110 & 25,7 & 5,7 & 5,7 & 23,6 & 23,6 \\
\hline 0,15 & 2189 & 26,3 & 4,0 & 4,7 & 19,7 & 23,2 \\
\hline 0,3 & 2300 & 28,1 & 2,1 & 3,0 & 14,9 & 21,3 \\
\hline 0,5 & 2418 & 30,7 & 0,2 & 0,4 & 11,6 & 23,2 \\
\hline
\end{tabular}

2 lentelè. Betonu su poringu stambiuoju užpildu (keramzitu) fizikinès ir mechaninès savybès

Table 2. Physical and mechanical properties of the concretes with porous coarse aggregate (expanded clay aggregate)

\begin{tabular}{|c|c|c|c|c|c|c|}
\hline \multirow[b]{2}{*}{$\varphi_{s t}$} & \multirow{2}{*}{$\begin{array}{l}\text { Tankis, } \\
\mathrm{kg} / \mathrm{m}^{3}\end{array}$} & \multirow{2}{*}{$\begin{array}{c}\text { Stipris } \\
\text { gniuždant, } \\
\text { MPa }\end{array}$} & \multicolumn{2}{|c|}{ Oro kiekis, \% } & \multicolumn{2}{|c|}{$\begin{array}{c}\text { Kapiliarinis } \\
\text { poringumas, } \%\end{array}$} \\
\hline & & & betone & $\begin{array}{c}\text { skiedi- } \\
\text { nyje }\end{array}$ & betone & $\begin{array}{c}\text { skiedi- } \\
\text { nyje }\end{array}$ \\
\hline \multicolumn{7}{|c|}{$\mathrm{V} / \mathrm{C}=0,4$} \\
\hline 0 & 2231 & 47,4 & 4,5 & 4,5 & 18,9 & 18,9 \\
\hline 0,15 & 2063 & 39,9 & 9,2 & 4,0 & 17,8 & 16,2 \\
\hline 0,3 & 1863 & 31,0 & 20,6 & 3,9 & 11,2 & 8,0 \\
\hline 0,5 & 1612 & 25,7 & 29,5 & 1,8 & 7,4 & 2,0 \\
\hline
\end{tabular}

Betono stiprumo sumažějimą, didèjant stambiojo užpildo koncentracijai, lemia ittempimy koncentracijos ir betono struktūros defektai, atsirandantys apie stambuji užpildą. Didesnis stiprumo sumažèjimas betonuose su tankiu užpildu pastebètas stambiojo užpildo koncentracijai $\varphi_{s t}$ didejant nuo 0 iki 0,15 . Betonuose su poringu stambiuoju užpildu (keramzitu) betono stiprumas proporcingai mažèja, stambiojo užpildo koncentracijai didèjant nuo 0 iki 0,5 .

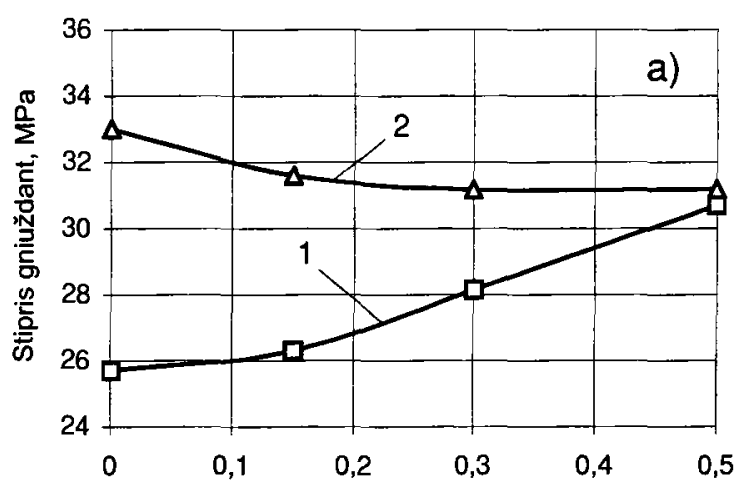

Stambiojo užpildo tūrinè koncentracija $\varphi_{s t}$

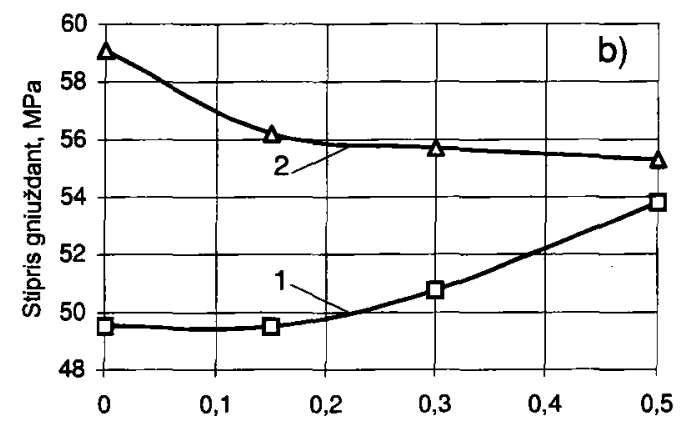

Stambiojo užpildo tūrine koncentracija $\varphi_{s t}$

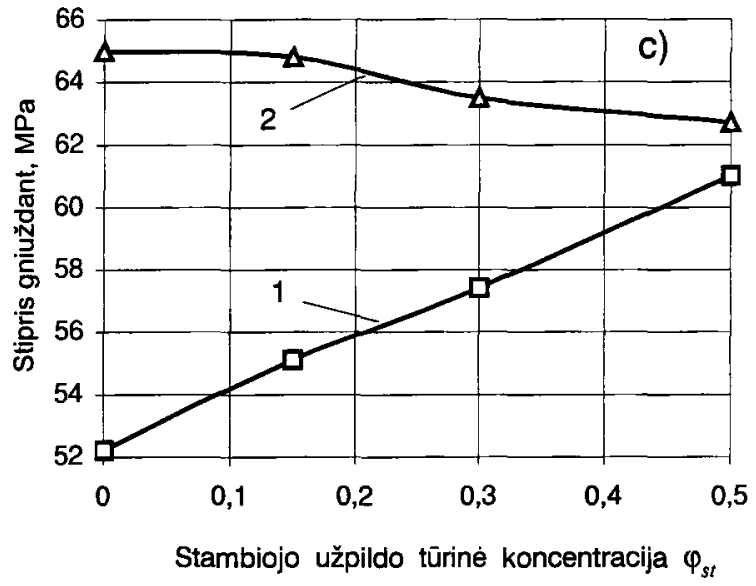

4 pav. Betono ( $\mathrm{V} / \mathrm{C}=0,6(\mathrm{a}) ; \mathrm{V} / \mathrm{C}=0,4(\mathrm{~b}) ; \mathrm{V} / \mathrm{C}=$ 0,3 (c)) stiprumo priklausomybė nuo stambiojo užpildo (granitinès skaldos) koncentracijos $\varphi_{s t}: 1-$ neivertinus oro kiekio betone; 2 - esant tam pačiam oro kiekiui betone

Fig 4. Relationship between compressive strength of concrete $(\mathrm{W} / \mathrm{C}=0.6(\mathrm{a}) ; \mathrm{W} / \mathrm{C}=0.4(\mathrm{~b}) ; \mathrm{W} / \mathrm{C}=0.3(\mathrm{c}))$ and volumetric concentration of coarse aggregate (crushed granite) $\varphi_{s t}: 1$ - concrete with current entrained air; 2 concrete with constant entrained air 


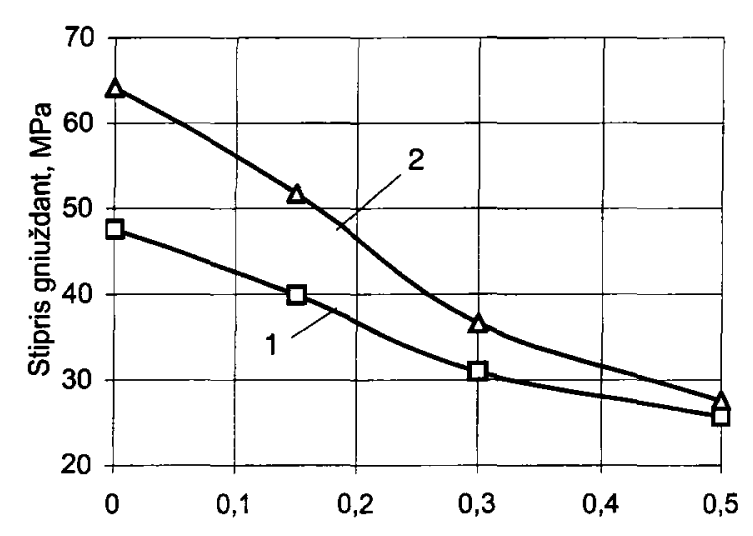

Stambiojo užpildo tūrinè koncentracija $\varphi_{s t}$

5 pav. Betono $(\mathrm{V} / \mathrm{C}=0,4)$ stiprumo priklausomybè nuo stambiojo užpildo (keramzito) koncentracijos $\varphi_{s t}: 1$ neivertinus oro kiekio betone; 2 - esant tam pačiam oro kiekiui betone

Fig 5. Relationship between compressive strength of concrete $(\mathrm{W} / \mathrm{C}=0.4)$ and volumetric concentration of coarse aggregate (expanded clay aggregate) $\varphi_{s t}: 1-$ concrete with current entrained air; 2 - concrete with constant entrained air

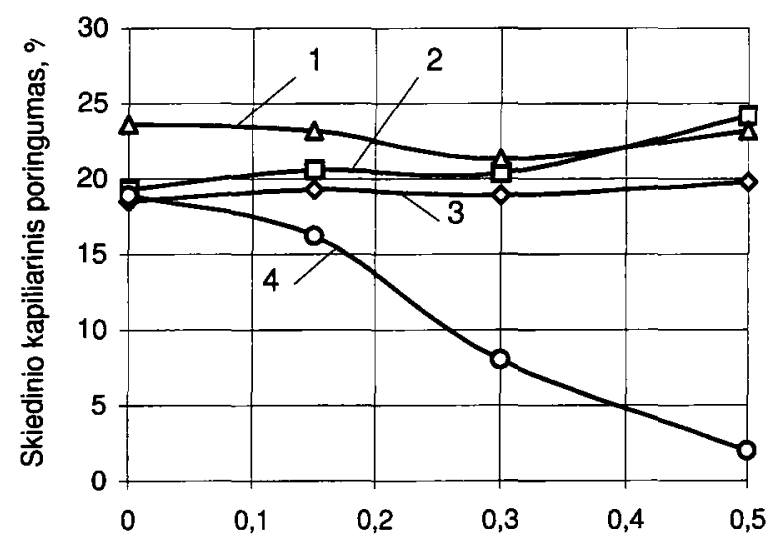

Stambiojo užpildo tūrine koncentracija $\varphi_{s t}$

6 pav. Betono skiedininès dalies kapiliarinio poringumo priklausomybè nuo stambiojo užpildo koncentracijos $\varphi_{s i}$ : 1 - betonas su tankiu stambiuoju užpildu, $\mathrm{V} / \mathrm{C}=0,6$; 2 - tas pats, $\mathrm{V} / \mathrm{C}=0,4 ; 3-$ tas pats, $\mathrm{V} / \mathrm{C}=0,3 ; 4-$ betonas su poringu stambiuoju užpildu, V/C $=0,4$

Fig 6. Relationship between capillary porosity of concrete mortar and volumetric concentration of coarse aggregate $\varphi_{s t}: 1$ - concrete with dense coarse aggregate, $\mathrm{W} / \mathrm{C}=0.6 ; 2$ - the same, $\mathrm{W} / \mathrm{C}=0.4 ; 3$ - the same, $\mathrm{W} / \mathrm{C}=0.3$; 4 - concrete with porous coarse aggregate, $\mathrm{W} / \mathrm{C}=0.4$

Stambusis užpildas turi itakos ir betono skiedininès dalies struktūrai. Kadangi tankaus stambiojo užpildo vandens igeriamumas labai mažas, jis nepakeičia vandens kiekio skiedinyje ir todèl skiedinio kapiliarinis po-

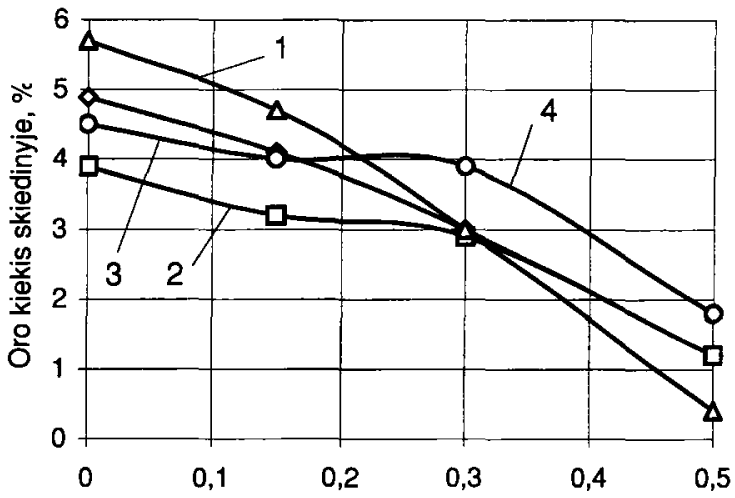

Stambiojo užpildo tūrinè koncentracija $\varphi_{s t}$

7 pav. Oro kiekio betono skiedininèje dalyje priklausomybè nuo stambiojo užpildo koncentracijos $\varphi_{s t}: 1$ betonas su tankiu stambiuoju užpildu, $\mathrm{V} / \mathrm{C}=0,6 ; 2$ tas pats, $\mathrm{V} / \mathrm{C}=0,4 ; 3$ - tas pats, $\mathrm{V} / \mathrm{C}=0,3 ; 4$ betonas su poringu stambiuoju užpildu, V/C $=0,4$

Fig 7. Relationship between entrained air content in the concrete mortar and volumetric concentration of coarse aggregate $\varphi_{s t}: 1$ - concrete with dense coarse aggregate, $\mathrm{W} / \mathrm{C}=0.6 ; 2$ - the same, $\mathrm{W} / \mathrm{C}=0.4 ; 3$ - the same, $\mathrm{W} / \mathrm{C}=0.3 ; 4$ - concrete with porous coarse aggregate, $\mathrm{W} / \mathrm{C}=0.4$

ringumas išlieka pastovus, didejjant tankaus stambiojo užpildo koncentracijai (6 pav.). Poringas stambus užpildas (keramzitas) pasižymi dideliu vandens igeriamumu (daugiau nei 16\%), dèl ko, didèjant stambiojo užpildo koncentracijai betone, žymiai sumažèja vandens kiekis betono skiedinineje dalyje ir jos kapiliarinis poringumas ( 6 pav.). Dèl minètu reiškinių padidejja betono skiedininès dalies stiprumas, kas dar labiau padidina skirtumą tarp stambiojo užpildo ir skiedininès dalies stiprumų. Kai užpildo stiprumas žymiai mažesnis už skiedinio stipruma, susidaro didelès tempimo ịtempimų koncentracijos virš ir po stambiuoju užpildu (1 pav.), kurios labai sumažina betono stiprumą ( 3 pav.). Šiuos samprotavimus patvirtina bandinių suirimo pobūdis - gniuždomi bandiniai suiro, atsiradus plyšiams, lygiagretiems su apkrovos veikimo kryptimi, visame bandinio tūryje.

Didelị betono su poringu užpildu skiedininès dalies stiprumą patvirtina betoninių bandinių skelto paviršiaus vaizdas ( 3 pav.). Betono su poringu stambiuoju užpildu irimas vyksta per užpildo daleles, o ne per skiedinio ir užpildo kontakto zoną, kaip būna bandant betoną su tankiu stambiuoju užpildu.

Oro kiekis betony tiek su tankiu, tiek su poringu stambiuoju užpildu skiedininèje dalyje proporcingai mažèja, didejjant stambiojo užpildo koncentracijai (7 pav.). 
Oro kiekis labiau sumažejja didesnio plastiškumo betono mišiniuose. Oro kiekio kitimas skiedininèje betono dalyje nepriklauso nuo stambiojo užpildo poringumo, kadangi tiek tankaus, tiek poringo stambiojo užpildo savitasis paviršius toks pats, kas ir turi didžiausios ittakos oro kiekiui skiedinyje ir betono mišinyje.

Stambiojo užpildo neigiamas poveikis betono stiprumui gniuždant atsiranda ir dèl silpnesnio stambių dalelių sukibimo su cementiniu akmeniu, nes cementinio akmens ir užpildų sukibimas didēja, mažejjant užpildụ dydžiui [12].

Tyrimai rodo, kad atitinkamai parinkus stambiojo užpildo savybes ir jo kieki betono mišinyje, galima sumažinti itempimu koncentracijas betone, atitolinti plyšiu susidarymo procesus, padidinti betono stiprumą ir išplèsti betono panaudojimo galimybes.

\section{Išvados}

1. Didejant tiek tankaus, tiek poringo stambiojo užpildo koncentracijai, oro kiekis betono skiedininèje dalyje ir betone mažèja, t. y. mažèja uždaras betono skiedininès dalies poringumas.

2. Atviras (kapiliarinis) betono skiedininès dalies poringumas, didejjant stambiojo užpildo koncentracijai, keičiasi nežymiai, kai stambusis užpildas tankus, ir žymiai sumažèja, didèjant stambiojo poringo užpildo koncentracijai.

3. Betono stiprumui gniuždant, esant tai pačiai skiedininès dalies sudecciai, daugiausia itakos turi du veiksniai: oro kiekis arba uždaras betono poringumas ir stambiojo užpildo kiekis bei jo stiprumas.

4. Esant tam pačiam oro kiekiui betone ir tai pačiai skiedininès dalies sudéčiai, didejjant stambiojo užpildo koncentracijai, betono stipris gniuždant mažéja dèl struktūrinių defektı ir ịtempimų koncentracijų, kurios susidaro apie stambuji užpildą.

5. Stambiojo užpildo koncentracijos itaką betono stiprumui ir oro kiekiui jame būtina ivertinti projektuojant betono mišinius.

\section{Literatūra}

1. А. Е. Десов. Пути попучения и область применения высокопрочного бетона // Бетон и железобетон, № 3, 1969 , c. $7-12$.

2. Г. А. Калниньш, И. А. Калис. Керамзитогазобетон для несущих конструкций зданий. Рига: Зинатне, 1976. $128 \mathrm{c}$.
3. И. Н. Ахвердов, А. Е. Смольский, В. В. Скочеляс. Моделирование напряженного состояния бетона и железобетона. Минск: Наука и техника, 1973. 232 с.

4. А. С. Дмитриев. Влияние крупного заполнителя на прочность и деформативность высокопрочного бетона // Вопросы общей технологии и ускорения твердения бетона. М.: Стройиздат, 1973, с. 24-34.

5. О. Я. Берг, Е. Н. Шербаков, Н. Г. Хубова. О пространственном напряженном состоянии бетона при одноосном сжатии // Известия ВУЗОВ. Строительство и архитектура, № 2, 1972, с. 8-13.

6. О. Я. Берг, Н. Г. Хубова, Е. Н. Щербаков. Разрушение контакта между заполнителем и раствором при сжатии бетона // Известия ВУЗОВ. Строительство и архитектура, № 8, 1972, с. 13-17.

7. N. J. Carino. A discussion of the paper "The Influence of Premix Polymer Additives on the Deformation Behavior of Concrete" by D. J. Cook and V. Sirivivatnanon // Cement and Concrete Research, Vol 8, No 5, 1978, p. $775-778$.

8. Н. И. Нетеса. Механика и технология бетонов. КиевДонецк: Виша школа, 1987. $146 \mathrm{c}$.

9. С. М. Сергеев, В. А. Беккер, В. В. Бездеиев. Моделирование напряженного состояния растворной части вокруг гранул крупного заполнителя бетона при действии на него внешней сжимающей нагрузки // Известия ВУЗОВ. Строительство и архитектура, № 5 , 1982 , c. $21-25$.

10. F. Larrard, A. Belloc. The Influence of Aggregate on the Compressive Strength of Normal and High-Strength Concrete // ACI Materials Journal, Vol 94, No 5, 1997, p. $417-426$.

11. В.Н. Шмигальский. Виброуплотнение бетонных смесей // Технологическая механика бетона: Сборник научных трудов. Рига, 1985, с. 115-127.

12. S. Walker, D. L. Bloem. Effects of Aggregate Size on Properties of Concrete // Journal of the American Concrete Institute, Vol 57, No 3, 1960, p. 283-298.

Iteikta 20010120

THE INFLUENCE OF COARSE AGGREGATE CONCENTRATION ON THE STRENGTH OF CONCRETE AND ON THE POROSITY OF CONCRETE MORTAR

\section{G. Skripkiūnas, V. Vaitkevičius}

Su m mary

The results of experiments dealing with coarse aggregate concentration influence on the concrete strength and the structure of hardened cement paste and mortar of concrete are presented in the paper.

Experiments were performed on concrete with dense coarse aggregate (crushed granite) which strength is more than strength of mortar and lightweight porous aggregate (expanded clay aggregate) with strength less than that of mortar. Physical and mechanical properties of concrete with dense coarse 
aggregate are presented in Table 1 and the concretes with the porous coarse aggregate in Table 2 . The decrease of entrained air content with the increase of coarse aggregate concentration $\varphi_{\sigma}$ were determined both for concretes with dense and porous coarse aggregate. The entrained air has a significant effect on concrete strength $-1 \%$ of entrained air decreases the strength of concrete about $5 \%$ [11]. The influence of the coarse aggregate concentration on the compressive strength of concrete with the constant air content is presented in Figs 3 and 4 . With the increase of coarse aggregate concentration the concrete strength decreases when the entrained air content in concrete is constant. The main reasons of the concrete strength reduction are the stress concentration and structural defects near the coarse aggregate.

Coarse aggregate affects the structure of mortar. Dense coarse aggregate has negligible water absorption and does not change water content in mortar of concrete, and capillary porosity of mortar remains constant when the concentration of dense coarse aggregate $\varphi_{s t}$ increases (Fig 5). Porous coarse aggregate (expanded clay aggregate) has large water absorption (more than 16\%), therefore water content in mortar of concrete is reduced and capillary porosity of mortar is significantly reduced when the concentration of porous coarse aggregate $\varphi_{s t}$ increases (Fig 5).

The entrained air content in mortar with both dense and porous coarse aggregate decreases inverse proportionally to coarse aggregate concentration $\varphi_{s t}$ (Fig 6).
The investigations have shown that suitable selection of properties and volumetric concentration of coarse aggregate can reduce stress concentration in concrete and increase the concrete strength.

Gintautas SKRIPKIŪNAS. Doctor, Associate Professor. Dept of Building Materials, Kaunas University of Technology (KTU). Studentų St. 48, LT-3031 Kaunas, Lithuania. E-mail: Gintautas.Skripkiunas@saf.ktu.lt

A graduate of KTU (1985). Doctor (1994). From 1994 Head of the Dept of Building Materials at KTU. Member of Board of Lithuanian Association of Construction Industry, member of American Concrete Institute (ACI). Research interests: concrete structure and properties, concrete durability, concrete technology.

Vitoldas VAITKEVIČIUS. MSc, Assistant. Dept of Building Materials. Kaunas University of Technology (KTU). Studentu St. 48, LT-3031 Kaunas, Lithuania.

E-mail: Vitoldas.Vaitkevicius@saf.ktu.lt

A graduate of Civil Enginering Faculty of KTU (1994). Doctoral studies at KTU (1995-2000). Research interests: concrete properties, high-strength concrete, concrete technology. 